\title{
Gastronomy and creative entrepreneurship in rural tourism: encouraging sustainable community development
}

\author{
Annelie Sjölander-Lindqvist, Anna de Jong, Romà \\ Garrido Puig, Giuseppa Romeo and Wilhelm Skoglund
}

\section{Introduction}

The tourism sector and associated planning processes are increasingly considered important arenas for facilitating territorial economic, social and ecological sustainability (McAreavey and McDonagh 2011; WTO 2018). This includes the rediscovery of tangible and intangible natural and cultural resources, which both entrepreneurs and planners understand to be vital for rural development (cf. Boniface 2001; Skoglund and Sjölander-Lindqvist 2020). Within development policies, sustainability narratives are heavily utilized to emphasize the potentials of gastronomy tourism as a form of diversification for rural and urban areas. According to the Framework Convention on Tourism Ethics (WTO 2017), tourism has the potential to contribute, both directly and indirectly, to the achievement of sustainable development as outlined in Agenda 2030. Tourism, featured as a target for inclusive and sustainable economic growth, sustainable consumption/production and the sustainable use of land, oceans and marine resources, can be a powerful driver for the revitalization of, for example, redundant buildings and open spaces. It can also provide opportunities for sustaining traditional and contemporary cultural values. This requires raising awareness among different actors of the role historical, cultural and social factors can play in the sustainable management of heritage resources (Fava and Guardia Bassols 2017; de Jong and Varley 2018; 
McAreavey and McDonagh 2011), as well as understanding the potentials and limitations of current efforts, policies and agendas.

Recognizing these imperatives, the GASTROCERT project studied the opportunities and limitations associated with gastronomy initiatives at regional levels in different European settings. The project focused on four European locations; it explored the conditions, opportunities and limitations associated with gastronomy and entrepreneurship in rural tourism. We included Calabria in Italy, the Girona province of Catalonia, the Highlands of Scotland and Jämtland in Sweden in our study to develop and support greater critical understanding of gastronomic heritage as a means of stimulating business competitiveness and balancing the globalization-caused fragmentation of local livelihoods (Jamal and Stronza 2009).

The four regions share with many other rural areas the trends of shrinking agricultural and fishing sectors, outmigration, declining service provision and reduced tax income bases, industrial transformation, ill health and environmental challenges such as climate change, reduced biodiversity and anthropogenic effects. In such areas, there exists a need to find ways to diversify the economy to increase employment, enlarge the tax base and support sustainable business revenue growth (Hjalager 1996; Johns and Mattsson 2005). A study of how gastronomy efforts and associated planning processes worked in such contexts was understood to enhance knowledge regarding the relationship between localized food production inspired by cultural heritage, tourism and planning.

\section{Conceptual framing: gastronomy, rurality and creativity}

To address the fragmented character of European rural areas and to allow understanding of the power dynamics and the potential of each region's rich natural larder and extensive food heritage, the study concerned itself with the construction through which gastronomy, entrepreneurship and rural tourism intersect. To reaffirm the importance of interdisciplinary critical research, participatory exercises were carried out at the local level in which participants from the public sector, non-governmental organizations, businesses and academia explored and identified the nuances and complexity of practice. This component aimed to support dialogue across sectors (Marcianò and Romeo 2019). 
The study began from 'gastronomy' as an all-encompassing approach to food and drink, relating to the cultural and material processes through which certain things become consumable (Richards 2002; Scarpato 2002); and the notion of the 'rural' as embracing the social, cultural and economic dimensions of the human presence in areas beyond those more densely populated (Butler 2011).

The concepts of 'creativity' and 'creative entrepreneurship' were used to understand entrepreneurial efforts in the sector and how these businesses, in order to be competitive, add something 'more' and 'new' (Pine II and Gilmore 1998). In other words, through using human and creative capital such as collective memories, traditional skills or local renowned people, the entrepreneurs, building symbolic value, bring new dimensions to development. This innovative use of different cultural dimensions, and the tangible and intangible properties of places and landscapes, supports the development and creation of new employment opportunities and stimulates economic growth (Johannisson 1990). Further arguments are provided by Pine II and Gilmore (2014), who state that businesses, to be competitive, must customize products and charge them with authenticity: a development that will eventually transform business behaviour throughout the advanced economies. While criticized for lacking conceptual rigour (Galloway and Dunlop 2007), the creative economy approach is also valued because it unites people who are passionate in their desire to reshape places, work, art, cities and so on (Howkins 2001 [2013]). It has arisen as more or less unavoidable in redirecting the futures of deindustrialized places and areas (Hesmondhalgh 2002). Increasingly utilized in cultural policy and hospitality-industry strategies and agendas, 'gastronomy tourism' is acknowledged as an opportunity to encourage agriculture, support local businesses and enhance the visitor experience, hence supporting strengthened cultural identity and a connection between people, places and cultural landscapes (Richards 2011; Sims 2009). Also, instead of globalization fostering cultural homogenization and disrupted places (Everett and Aitchison 2008; Ritzer 2011), distinctiveness is promoted through local entrepreneurship, policy measures and tourism development efforts (de Jong and Varley 2018).

Creative-industry development and tourism can of course have both positive and negative outcomes for communities and the preservation of natural and cultural resources. Benefits include community pride, provision of jobs and household income, building of social capital and a stronger sense of cultural identity (Besculides et al. 2002). Through the practices of production and consumption, a sense of belonging to an area is created and reinforced (Sjölander-Lindqvist and Cinque 2014). There may also be disbenefits. Such consequences include disrupted connections to land for residents; hierarchization when certain heritage is celebrated while other memories, traditions 
and practices are not proclaimed as valuable resources; and degradation of ecosystems (Briassoulis 2002). There may also be disputes when community members experience development in this direction as augmenting dilution and gentrification when planners prioritize idyllic settings to attract tourists before the continuous support of, for example, local fisheries (George et al. 2009; Stockdale 2010). In this sense, gastronomy can be a tourism resource of cultural value that might be representative of peoples and territories (Armesto and Gómez 2006) and contribute to the identity formation of postmodern societies (Richards 2002). However, if not elaborated, social injustice grows, negative environmental conditions intensify and economic revenues drop when tourists become disappointed with the values offered by the destination (Briassoulis 2002).

\section{At the intersection of rural tourism, gastronomy and entrepreneurship}

Food and gastronomy-related activities are important because they add vitality to rural communities. In Jämtland and the Highlands, a craft beer trend is stimulating the development of small-scale craft breweries (Figure 16.1). As the interest in and status of craft beer have increased, so has the demand to visit the cities and towns, production sites and people behind these beers (Nilsson 2007; Skoglund and Sjölander-Lindqvist 2020). The growing interest in 'local' food and drink, celebrating and fostering authenticity and the link between producer and place, contests global food homogenization (Everett and Aitchison 2008; Leitch 2003); it is also a way to encourage everyday life, small-scale agricultural practices and handcrafted food preparation for sustainable development at a regional level. This trend, referred to by some as 'normative localism' (DuPuis and Goodman 2005) or as 'neolocalism' (Flack 1997; Pezzi 2017), denotes, in short, a desire to 'reconnect' (Fava et al. 2018; Kneafsey et al. 2008) the producer with the consumer. It also illustrates associations between a particular product or service and the producer, through place, landscape and cultural identities (Kneafsey et al. 2008). This is seen not least in the case of craft beer production in Jämtland, where the producers name the beers after a certain locally known place, sceneries of landscape and places or local people (Skoglund and Sjölander-Lindqvist 2020).

Potential for destination development is acknowledged both nationally and internationally, but effective implementation requires awareness of several complicating factors. One of the sources of tension is how to expand production without losing the fundamental 'local' and 'traditional' attributes. Indeed, 


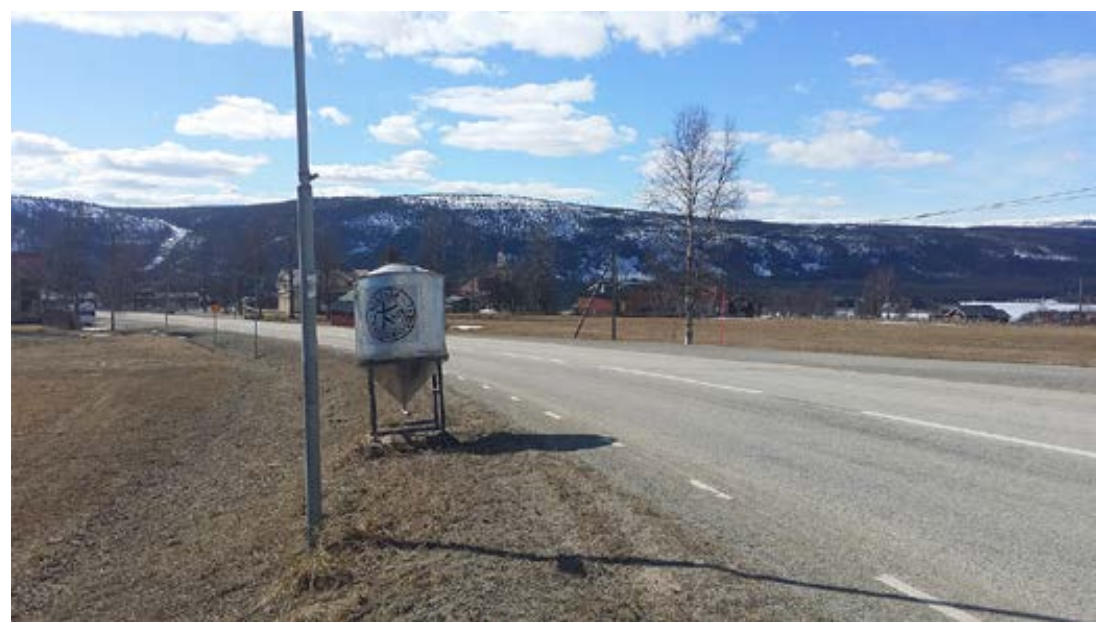

Source: Wilhelm Skoglund.

Figure 16.1 Brewery in Jämtland, Sweden

increased production levels might 'devalue' the local produce, be it through self-imposed or formal certification demands. In the case of the certified Calabrian Caciocavallo di Ciminà cheese, it is difficult to scale up production because the cheese must be produced with milk obtained from cows that graze on local pasture for as long as they can. When this is not possible, the process itself has to shift and the cultural heritage connection is diluted. Another tension is that entrepreneurs might not primarily aim at growth in a 'traditional' sense. Instead of increasing revenues, raising profits or growing in size, several take an alternative road, centring their work on other dimensions: the social and the cultural but also the ecological. This is, in business terms and in the context of the growth economy, a rather unusual perspective; it links with the concept of community entrepreneurship in which the notion of the local and immediate environment of the entrepreneur motivates and legitimizes activity (Johannisson 1990). In our study, the entrepreneurs demonstrated a strong wish to contribute to development, based on a desire to strengthen local community spirit and livelihoods (Palladino et al. 2019). A sustainable and trustworthy destination development discourse should therefore include greater awareness among policymakers that small-scale producers are often driven by passion, lifestyle choices and care of the local context and community, as well as maintaining value by remaining flexible, small and sustainable. However, according to several of our studied entrepreneurs, policymakers often tend to focus more on traditional economic growth perspectives such as 
scaling up production, exporting and growing in numbers. It is also important to question if local food promotion is effective in destinations with low average income, limited carrying capacity and long distribution routes. If policymakers and entrepreneurs find it viable to promote gastronomy and tourism efforts, these limitations and opportunities (such as the emerging trends of recycling of food waste into food products, vegan food, element hospitality and slow adventure tourism) should be discussed and considered against local and regional development dimensions.

The attractions of marketing distinctive food practices, ingredients and styles to visitors may also come with significant global economic, social and environmental impacts (Briassoulis and van der Straaten 2013). User pressure, including increased energy consumption and subsequent emissions (tourism contributed approximately 5 per cent to global anthropogenic emissions of $\mathrm{CO}_{2}$ in 2005); sewage; litter; cultural commodification; wage inequality; absentee ownership and other consequences often follow leisure and tourism development (UNEP 2012). With around 1.2 billion tourists travelling around the world, tourism represents approximately 10 per cent of world gross domestic product (GDP), one in ten jobs and 7 per cent of global exports. In addition to its environmental impact, it has a decisive capacity to contribute to the achievement of the social and economic goals of the 2030 Agenda. This calls for actions that can support environmental protection and landscape diversity, while also providing livelihood opportunities in the broadest terms. While tourism can be harmful to the support systems for the unique qualities of places and landscapes, it may also be an important driver of diversification, innovation and employment (Hjalager 1996).

Another ecological sustainability challenge was detected in craft beer production, where producers felt the need to import hops and malt from the US, New Zealand and central Europe in order to enable consistent high-quality production of pale ales and similar types of ales or beers. Processes have started to replace these grains with locally grown ones, which could further charge the products with 'local value', as well as lowering the environmental impact of production.

\section{Successful support measures}

While there are environmental challenges, gastronomic heritage and its role in tourism development in rural areas can aid economic and social resilience. Our study reveals a number of favourable activities that respect this fine line. From 
a policy perspective, a beneficial path could be to increase the size of ancillary activities to support entrepreneurial diversification, which is often a necessary livelihood strategy in remote locations. As we have found, strengthened support systems for tourism and the cultural and creative industries could include providing common transport and logistics systems, arranging traditional business courses and inspiring further exchange of knowledge and opportunities to collaborate with other gastronomy actors. The availability of locally sourced food not only shortens transportation routes but also plays an important role in bringing cities and rural communities together. By improving low-cost and environmentally friendly opportunities for distribution and logistics of goods, alternative economies and creative livelihood solutions can prosper. Such development supports and sustains rural development.

Additionally, public markets, festivals and celebrations are also significant in attracting tourists searching for 'authentic' experiences and 'local' produce that can bring them closer to the local region and day-to-day social practices (Fava et al. 2018; Nicolosi et al. 2017). It is therefore important to provide opportunities such as food markets for the tasting and buying of products that come from the region. Cooking workshops, as offered by the Espai del Peix in Palamós, Girona, where fresh fish unloaded at the port and its culinary heritage are promoted, is an example of an activity that can support awareness and interest in local gastronomy and livelihood traditions.

As a further example, although in decline, the fishing industry remains of high cultural significance on Scotland's west coast. For this reason, tourism actors value the symbols, performances and discourses of the fishing industry in the development of tourist destinations. In organizing a local food festival in the Scottish town of Mallaig, organizers focused on reinterpreting the spaces and symbols of the fishing industry, in attempts to add authenticity to the food tourism experience. Images of 'fresh', 'wild' langoustines, scallops, crab and herring, and the hard-working, working-class, masculine fisherman were central framings through which marketing promotion unfolded, ensuring that the fishing industry remained central to the concerns of the tourist industry (de Jong and Varley 2018). Hence, tourism might cause changing roles and responsibilities within rural communities where those from the tourism industry and the policy sector hold the potential to determine place development. Dialogue and collaboration between actors must be in place to build a deepened sense of cohesion across levels. 


\section{Conclusion}

In these times, gastronomy has moved far beyond a focus on the consumption of food and drink. Connections between taste, culture and production are important not only to tourists but also to the entrepreneurs themselves. For example, when craft beer brewers refer to local mythology in company names, product stories and product names, they build a competitive edge (Murray and Kline 2015). They do this also by relating to natural, cultural and social worlds and reproducing collective memories, cultural heritage and socially binding frameworks (Zerubavel 1996). When human and creative capital are used instead of price in the competition for consumers' interest, a web of images and feelings associated with the locality - which includes traits of landscape, cultural heritage and people - is woven, and a sense of belonging to the area is created or reinforced (Sjölander-Lindqvist and Cinque 2014). This suggests that entrepreneurship is more than an economic pursuit: it is an inherently social practice that is part of a certain sociocultural milieu. From this perspective, the entrepreneur is a mediating agent whose acts reflect distinct social and cultural spheres and coincide with how mnemonic entrepreneurship informs the revitalization of rural areas (Sjölander-Lindqvist and Cinque 2014). Hence, the social and cultural dimensions of food make it a feasible and potential 'vehicle' for innovation and knowledge-creation that can support and drive regional development. This emphasizes its relevance for rural and regional business and policy development strategies, as well as its value in terms of research within rural development connected to tourism. The findings of this study are applicable to similar rural regions where gastronomy is picking up pace and producing direct and indirect opportunities in relation to employment and new business development.

Policy is often built upon traditional industrial paradigms, with growth and profit as key components. Small-scale food producers are often driven by passion, lifestyle choices and care of the local context and community, as well as by a philosophy to remain flexible, small and sustainable. As entrepreneurs place emphasis on sustainability matters, utilizing local and regional gastronomy in tourism has the capacity to serve as somewhat of a role model in business development, thereby increasing attractiveness and symbolic value among local and external consumers, as well as boosting tourism development opportunities. Developing sustainable and trustworthy destination development discourse should include the building of stronger linkages between producers, service providers and policymakers. Future studies should therefore be attentive towards the capacity of local food promotion to be an effective and sustainable means for development in destinations with low average income, 
limited carrying capacity and long distribution routes. If policymakers and entrepreneurs find it viable to promote gastronomy and tourism efforts, this viability needs to be further explored. So also do the role of networking and collaboration in overcoming the barriers and obstacles of being small and peripheral, and how disadvantages in terms of location can be turned into something with positive value.

\section{References}

Armesto, X.A. and B. Gómez (2006). 'Tourism and quality agro-food products: an opportunity for the Spanish countryside', Tijdschrift voor Economische en Sociale Geografie, 97 (2), 166-77.

Besculides, A., M.E. Lee and P.J. McCormick (2002), 'Residents' perceptions of the cultural benefits of tourism', Annals of Tourism Research, 29 (2), 303-19.

Boniface, P. (2001), Dynamic Tourism: Journeying with Change, Clevedon: Channel View Publications.

Briassoulis, H. (2002), 'Sustainable tourism and the question of the commons', Annals of Tourism Research, 29 (4), 1065-85.

Briassoulis, H. and J. Van der Straaten (2013), Tourism and the Environment: Regional, Economic, Cultural and Policy Issues, Dordrecht: Springer Science+Business Media, B.V.

Butler, R.W. (2011), 'Sustainable tourism and the changing rural scene in Europe', in D.V.L. Macleod and S.A. Gillespie (eds), Sustainable Tourism in Rural Europe, London and New York: Routledge, 15-27.

De Jong, A. and P. Varley (2018), 'Food tourism and events as tools for social sustainability', Journal of Place Management and Development, 11 (3), 277-95.

DuPuis, E.M. and D. Goodman (2005), 'Should we go "home" to eat? Toward a reflexive politics of localism', Journal of Rural Studies, 21 (3), 359-71.

Everett, S. and C. Aitchison (2008), 'The role of food tourism in sustaining regional identity: a case study of Cornwall, South West England', Sustainable Tourism, 16 (2), 150-67.

Fava, N. and M. Guardia Bassols (2017), 'Territori del cibo e nuovi spazi di socialità', in L. Fontana (ed.), Food and the City, Venezia: Marsilio, 225-36.

Fava, N., M. Carrasco Bonet and R. Garrido Puig (2018), 'Foodsheds and the role of public markets in the Provincia of Girona', in J. Schröder, M. Carta, M. Ferretti and B. Lino (eds), Dynamics of Periphery. Atlas for Emerging Creative and Resilient Habitat, Berlin: Jovis Verlag GmbH, 238-50.

Flack, W. (1997), 'American microbreweries and neolocalism: "Ale-ing” for a sense of place', Cultural Geography, 16 (2), 37-53.

Galloway. S. and S. Dunlop (2007), 'A critique of definitions of the cultural and creative industries in public policy', International Journal of Public Policy, 13 (1), 17-31.

George, E.W., H. Mair and D.G. Reid (2009), Rural Tourism Development - Localism and Cultural Change, Bristol: Channel View Publications.

Hesmondhalgh, D. (2002), The Cultural Industries, London: Sage.

Hjalager, A.M. (1996), 'Agricultural diversification into tourism: evidence of a European Community development programme’, Tourism Management, 17 (2), 103-11. 
Howkins, J. (2013), The Creative Economy: How People Make Money from Ideas, London: Penguin. Originally published 2001.

Jamal, T. and A. Stronza (2009), 'Collaboration theory and tourism practice in protected areas: stakeholders, structuring and sustainability', Sustainable Tourism, 17 (2), 169-89.

Johannisson, B. (1990), 'Community entrepreneurship - cases and conceptualization', Entrepreneurship and Regional Development, 2 (1), 71-88.

Johns, N. and J. Mattsson (2005), 'Destination development through entrepreneurship: a comparison of two cases', Tourism Management, 26 (4), 605-16.

Kneafsey, M., R. Cox, L. Holloway, E. Dowler, L. Venn and H. Tuomainen (2008), Reconnecting Consumers, Producers and Food: Exploring Alternatives, Oxford: Berg.

Leitch, A. (2003), 'Slow food and the politics of pork fat: Italian food and European identity', Ethnos, 68 (4), 437-62.

Marcianò, C. and G. Romeo (2019), 'Action research and participatory decision-aid models in rural development: the experience of "Terre Locridee" local action group in Southern Italy', in F. Calabrò, L. Della Spina and C. Bevilacqua (eds), New Metropolitan Perspectives, Cham: Springer, 29-41.

McAreavey, R. and J. McDonagh (2011), 'Sustainable rural tourism: lessons for rural development', Sociologia Ruralis, 51 (2), 175-94.

Murray, A. and C. Kline (2015), 'Rural tourism and the craft beer experience: factors influencing brand loyalty in rural North Carolina, USA', Journal of Sustainable Tourism, 23 (8/9), 1198-216.

Nicolosi A., L. Cortese, G. Romeo, V.R. Laganà, M. Petullà and C. Marcianò (2017), 'Erratic behavior and beauty of Costa Viola: sea villages heroic viticulture and gastronomic tourism', Proceedings of the 20th IPSAPA/ISPALEM International Scientific Conference, Udine, 269-87.

Nilsson, M. (2007), Den hemlige kocken. Det okända fusket med maten på din tallrik, Stockholm: Ordfront.

Palladino, M., C. Cafiero and C. Marcianò (2019), 'The role of social relations in promoting effective policies to support diversification within a fishing community in Southern Italy', in F. Calabrò, L. Della Spina and C. Bevilacqua (eds), New Metropolitan Perspectives, Cham: Springer, 124-33.

Pezzi, M.G. (2017), 'From peripheral hamlet to craft beer capital: Appechio and the Alogastronomia', Italian Journal of Planning Practice, 7 (1), 154-85.

Pine II, B.J. and J.H. Gilmore (1998), 'Welcome to the experience economy', Harvard Business Review, July-August, 97-105.

Pine II, B.J. and J.H. Gilmore (2014), 'A leader's guide to innovation in the experience economy', Strategy \& Leadership, 42 (1), 24-9.

Richards, G. (2002), 'Gastronomy: an essential ingredient in tourism production and consumption', in A-M. Hjalager and G. Richards (eds), Tourism and Gastronomy, London and New York: Routledge, 3-20.

Richards, G. (2011), 'Creativity and tourism: the state of the art', Annals of Tourism Research, 38 (4), 1225-53.

Ritzer, G. (2011), The McDonaldization of Society, Thousand Oaks, CA: Sage.

Scarpato, R. (2002), 'Gastronomy as a tourist product: the perspective of gastronomy studies', in A-M. Hjalager and G. Richards (eds), Tourism and Gastronomy, London and New York: Routledge, 51-70.

Sims, R. (2009), 'Food, place and authenticity: local food and the sustainable tourism experience', Sustainable Tourism, 17 (3), 321-36. 
Sjölander-Lindqvist, A. and S. Cinque, (2014), 'Locality management through cultural diversity', Food, Culture and Society, 17 (1), 143-60.

Skoglund, W. and A. Sjölander-Lindqvist (2020), 'Caring for community through crafted beer: perspectives from North Sweden', in G. Pezzi (ed.), Agritourism, Wine Tourism, and Craft Beer Tourism: Local Responses to Peripherality through Tourism Niches, London and New York: Routledge, pp. 208-25.

Stockdale, A. (2010), 'The diverse geographies of rural gentrification in Scotland', Journal of Rural Studies, 26 (1), 31-40.

UNEP (2012), Annual Report 2012. Division of Communications and Public Information.

WTO (World Tourism Organization) (2017), Framework Convention on Tourism Ethics. Madrid: UNWTO.

WTO (World Tourism Organization) (2018), Tourism for Development - Volume I: Key Areas for Action. Madrid: UNWTO.

Zerubavel, E. (1996), 'Social memories: steps to a sociology of the past', Qualitative Sociology, 19 (3), 283-99. 
Annelie Sjölander-Lindqvist, Anna de Jong, Romà Garrido Puig, Giuseppa Romeo, and Wilhelm Skoglund - 9781788974639 Downloaded from PubFactory at 04/26/2023 01:07:13PM 